\title{
Monetary economics after the global financial crisis: what has happened to the endogenous money theory?
}

\author{
Giuseppe Fontana* \\ University of Leeds, UK and University of Sannio, Italy \\ Riccardo Realfonzo \\ University of Sannio, Italy \\ Marco Veronese Passarella \\ University of Leeds, UK
}

\begin{abstract}
The 2010s have witnessed a new shift in central banking and, partially at least, in monetary economics and macroeconomic modelling. It is a fact that the endogenous money theory has been gradually clawing back popularity at the expense of the classical theory of interest rates, the financial intermediation view of banks, the money-multiplier story and the quantity theory of money. However, the loanable funds theory and the view of banks as pure financial intermediaries (sometimes coupled with the money-multiplier story) are still sometimes invoked. In addition, the dynamic process of creation, circulation and destruction of money is usually neglected. The point is that money endogeneity is still regarded by many mainstream economists as a mere empirical fact, not a key feature of capitalist market-based economies to be properly explained by a logically consistent theory. By contrast, dissenting economists have further advanced the endogenous money view through: (a) a generalised theory of the endogenous process of money creation; (b) the increasing popularity of modern monetary theory in the public debate; and (c) the development of aggregative stock-flow consistent models and agent-based stock-flow consistent models as an alternative to dynamic stochastic general equilibrium models.
\end{abstract}

Keywords: endogenous money, exogenous money, quantitative easing, inflation targeting, modern monetary theory, stock-flow consistent models

JEL codes: $B 52, E 12, E 51, E 52$

\section{INTRODUCTION}

According to Sir John Hicks, 'monetary theory ... belongs to monetary history' (Hicks 1967). It evolves in response to urgent problems faced by the economists and policy-makers under specific historical, social and institutional conditions. At the same time, as Joseph Schumpeter maintains, in the field of money some theoretical ideas can often be contradicted by practical considerations (Schumpeter 1954). Drawing on these insights, one of the goals of this paper is to critically assess recent developments in both mainstream and non-mainstream monetary

* Corresponding author: Email: G.Fontana@leeds.ac.uk.

Received 14 August 2019, accepted 25 November 2019 
economics, especially after the global financial crisis (GFC) of 2007-2008. Looking at the academic literature as well as the policies of central banks and other international institutions, endogenous money views have been gradually clawing back popularity at the expense of the classical theory of exogenous money, where the latter has often taken the form of the loanable funds theory of the interest rate, the pure financial intermediation view of banks, the (fixed and variable) money-multiplier analyses and the quantity theory of money (QTM) (Realfonzo 1998). Have mainstream economists and policy-makers finally embraced the endogenous money theory (EMT)? Alternatively, do they consider the endogeneity of the money supply as a mere historical accident, or an empirical expedient, a residual in a set of formal equations? On the other hand, have non-mainstream advocates of the EMT simply restated its main principles or have they made advances at the theoretical, empirical and policymaking levels? This paper tries to provide an answer to these questions.

Section 2 compares the exogenous and endogenous views of money. Section 3 deals with the mainstream theory and policy-making approach to endogenous money. We discuss the main features and limitations of the instrumentalist approach. Section 4 is devoted to the non-mainstream approaches to the EMT, covering the theoretical distinction between the horizontalist/single-period-structuralist/continuation-period approaches, the highly popular policy-making-led modern monetary theory (MMT) and recent developments in macromonetary modelling, namely stock-flow consistent (SFC) empirical models. Section 5 concludes.

\section{EXOGENOUS VS ENDOGENOUS MONEY-SUPPLY VIEWS}

The quantity theory of money, with the principles of the exogenous nature of the money supply and of the neutrality of money, is one the main pillars of neoclassical monetary economics and has dominated the debate in monetary economics up until the first decades of the twentieth century. However, the financial instability between the two world wars, the end of the Gold Standard and finally the establishment of the new international monetary system at Bretton Woods in 1944 created an increasing distance between the vast majority of academic economists, who defended neoclassical monetary economics, and most practitioners and central bankers, who were sceptical of it.

Of course, there is also a long tradition of dissenting academics who put forward analyses critical of neoclassical monetary economics and supporting the non-neutrality of money. Many of these academics were members of the Cambridge School (Kahn 1972; Kaldor 1970; Robinson 1956) and pioneers of the monetary circuit theory (MCT) (Le Bourva 1962; 1992; Schmitt 1960; 1972; 1975; 1984). This dissenting line of research in monetary economics has been further developed by other scholars since the late 1970s (for example, Davidson 1978; Godley/Cripps 1983; Graziani 1984; 1989; Kaldor 1982; Parguez 1984) and especially Basil Moore (1988) with his monumental Horizontalists and Verticalists: The Macroeconomics of Credit Money.

Today the so-called dominant 'New Consensus' model (NCM) in macroeconomics, established between the early 1990s and the mid 2000s, has replaced the old Monetarist rule of targeting monetary aggregates with an interest-rate rule (Cecchetti et al. 2006; Taylor 2004). According to the NCM, monetary policy is said to affect real variables and inflation in the short run, but is neutral in the long run, when prices are assumed to be flexible and expectations are fulfilled (Taylor 2000). The interest-rate rule is usually modelled as a reaction function of the central banker who aims at minimising a loss function including inflation and the output gap (Clarida et al. 1999; Romer 2000). Since prices are assumed to be sticky in the short run, the central bank fine-tunes the real interest 
rate by steering the nominal rate. In the NCM model, the central bank targets inflation, not the money supply. Money is a simple residual variable and in fact a rather volatile one. This is sometimes regarded as the proof that the current mainstream in macroeconomics has apparently embraced an endogenous money view.

\section{ENDOGENOUS MONEY: MAINSTREAM THEORY AND POLICY-MAKING}

\subsection{The instrumentalist approach to endogenous money}

Support for interest-rate-based, fine-tuning policies arose from empirical findings, thereby leading central banks to abandon monetary targets in favour of interest-rate targets (Blinder 1997). The very volatility of financial markets, compared with goods (and services) markets, is the key argument that is usually put forward by central bankers to justify the use of the interest rate as the main monetary policy tool (Fontana 2004). The instrumentalist approach is usually mentioned as a successful integration of the theory and practice of central banking (Laidler 2002), pushing mainstream economic theory to accept the idea that the main function of the central bank is to steer the base interest rate on the money market, whereas monetary aggregates adjust endogenously.

In dynamic stochastic general equilibrium (DSGE) models monetary aggregates are treated as a residual variable of the system of equations or considered as being very unstable (Bank of England 1999; Federal Reserve Board 1996). Similarly, leading monetary economists like Svensson (1999), J.B. Taylor (1999) and Woodford (1996) have increasingly acknowledged the endogeneity of monetary reserves and bank loans since 2000 (Fontana 2002).

On the theoretical side, the problem was initially addressed by a path-breaking article written by William Poole (1970), where alternative monetary policy options were evaluated in the context of a stochastic IS-LM model. Poole (1970) assumes that both the base interest rate and the money supply could be under the control of the central bank. The aim is to determine the conditions under which the former (the 'Keynesian' option) should be preferred to the latter (the 'Monetarist' option) as the best tool for monetary policy. It turns out that targeting monetary aggregates dampens the impact on income of disturbances to aggregate demand, whereas targeting the interest rate dampens the impact of disturbances to the demand for money. As a result, the interest rate is the optimal tool when the goods market (represented by the IS curve) is less volatile than the money market (the LM curve). By contrast, monetary aggregates should be the instrument of policy when the money market is more stable than the goods market. Therefore, the solution to the optimal choice problem can only come from empirical evidence. As the latter has usually been interpreted to suggest that since the early 1970s the LM curve is more volatile and unpredictable than the IS curve, interest-rate policies have gained momentum. Although more complicated models have been developed since, the key findings of Poole's approach, which is sometimes labelled 'central bank endogeneity' (Palley 2002), have remained almost unchanged (Fontana/ Palacio-Vera 2004; Friedman 1990). The main features of the instrumental (or empiricist) approach are summed up in the first row of Table $1 .^{1}$

1. The last three rows of Table 1 cover standard IS-LM Keynesianism (before Poole 1970), Monetarist approaches to money (that is, early Monetarism and the New Classical macroeconomics), and the real business cycle school. While the latter somewhat recognises the endogeneity of money supply, which adjusts endogenously to technical-innovation-driven economic fluctuations, the two Monetarist approaches simply advocate a return to the quantitative theory of money. For this reason, we do not discuss them in detail. 


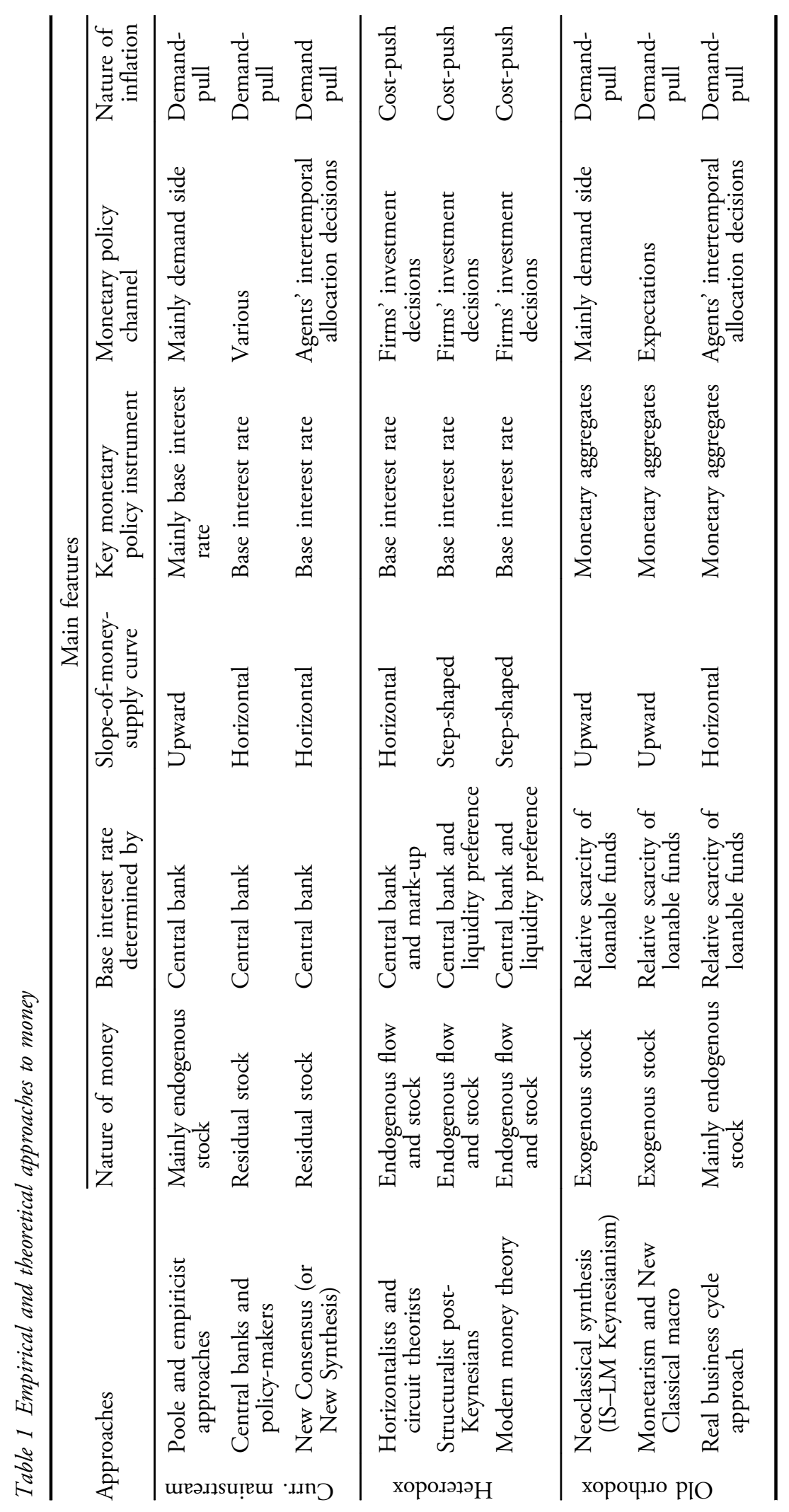




\subsection{Limitations of the instrumentalist approach}

There are some critical issues at the heart of the empiricist or instrumentalist approach to money endogeneity. First, Poole's model neglects the possible interconnection between the IS and the LM curves, meaning the interdependence between the goods markets and the monetary sector (Palley 1996a). Second, in Poole's model and a relevant part of the current mainstream literature, there is still the idea that central bankers could control monetary aggregates. However, most of the liquidity used by the public (households, firms and financial intermediaries) in modern economies is made up of bank deposits. The central bank may well try to influence the lending decisions of commercial banks, but it can determine neither the stock of money demanded by the private sector nor its growth rate (Fontana 2000; Wray 1998). Third, leaving aside the points made above, the impact of the chosen monetary policy regime on the volatility of the IS and LM curves is ignored. In Poole's model

the standard deviation of shocks to the monetary sector $\ldots$ and the covariances of shocks to the commodity and monetary sectors are assumed to be exogenous and, therefore, independent of the monetary policy regime implemented. But these parameters ... are likely to be a function of the monetary policy regime pursued by a central bank. (Fontana/Palacio-Vera 2004: 31)

More precisely, the implementation of a money-targeting regime would change the parameters of the model in such a way as to shift the balance in favour of an interest-rate-targeting regime. This means that 'the choice of a money-targeting regime is likely to be self-defeating' (ibid.). The very fact that over a long period of time no central bank has ever succeeded in finetuning money growth with precision (Bernanke et al. 1999) has raised many doubts about the possibility for monetary authorities to opt for a money-targeting regime, leading many mainstream commentators to argue that Poole's model overlooks the Lucas critique and it is vulnerable to a variant of Goodhart's law. Finally, the instrumental approach to money endogeneity is grounded in the empirical evidence that the IS function is more stable and predictable than the LM function: should the volatility of the goods market exceed the volatility of the money market, monetary aggregates would once again become the optimal monetary policy instrument. At the theoretical level, this explains why most leading economists do not seem to have rejected the quantity theory of money, the pure intermediation view of banks and the money-multiplier explanation of the money-supply process. The point is that the use of the base interest rate as the key policy tool is due to the temporary absence of a stable and predictable relation between monetary aggregates and nominal income, and not due to any theoretical rejection of the exogenous money view.

\subsection{Unconventional monetary policies and endogenous money}

The GFC of 2007-2008 and the related European sovereign debt crisis have brought attention to the effects and limitations of conventional and unconventional monetary policies. First, credit easing $(\mathrm{CE})$ and quantitative easing $(\mathrm{QE})$ programmes adopted by major central banks, officially in an attempt to bring back inflation rates to their target levels, have had a paradoxical effect on the debate on money. While such unconventional policies had a clear Monetarist origin, because of the restoration of monetary targets, they ended up showing that the fear of inflation due to an expansion in the money supply was groundless (Lavoie 2017). For instance, the increase in the money supply following QE programmes in the UK was initially smaller than the increase in monetary reserves. Similarly, the money multiplier in the US was found to have slipped below unity (Mankiw 2009), due to banks building up their 'excess reserves'. Similar observations were 
made for the euro area (De Grauwe/Ji 2013). These unexpected findings brought about a debate on the 'collapse of the money multiplier'.

Second, the two crises have been accompanied by a renewed debate on Keynes's notion of a liquidity trap (LT) and the policy implications of the zero lower bound (ZLB) for the interest rate. Although the two concepts are sometimes associated, they should be kept separated. As is known, when the short-term nominal interest rate is at (or near) zero, the capacity of the central bank to stimulate economic growth by lowering the cost of money is limited. This led many leading mainstream economists to argue that monetary policy is ineffective at the ZLB (Krugman et al. 1998) and has triggered a passionate debate on the ZLB (Adam/ Billi 2007; Gambacorta et al. 2014; Hamilton/Wu 2012; McCallum 2000; Summers 2014; Wright 2012; Wu/Xia 2016). The concept of an LT has also been linked to the notions of 'debt deflation' and 'financial instability' (Eggertsson/Krugman 2012). This literature considers the LT in terms of the technical impossibility of further reductions of the nominal interest rate at the ZLB, rather than in terms of the infinite preference for cash and gloomy expectations, or the lack of any prospect for a real recovery, which will make monetary policy powerless (Dow 2015; Keynes 1936; Kregel 2000).

Third, it has been argued that the QE could be complemented with a reduction in the interest rate that central banks pay commercial banks on their own (marginal) excess reserves. It is sometimes argued that this will provide banks with an incentive to increase their lending. However, many authors have recognised that cutting the interest rate on excess reserves (IOER) entails no significant effect in raising bank lending to the private sector. In addition, when the economy is stuck in an LT, central banks can buy bank bonds or even inject equity to help the banks expand (Goodhart 2013b). The truth of the matter, however, is that banks are firms in the business of making loans. If they do not extend credit, this is due to either the lack of profitable opportunities or the lack of demand for loans. In these circumstances, expansionary fiscal policies seem to be the only way to reflate a distressed economy (Lavoie 2017).

Finally, the GFC has called into question the so-called full independence of central banks, as the latter need to coordinate with governments to steer the overnight interest rate and undertake unconventional monetary policies. In a sense, central banks can only carry out 'defensive' operations, as they cannot control the demand for monetary reserves (Bindseil 2004; Fullwiler 2003; 2013). So, unsurprisingly, many researchers and officials at leading central banks and other supra-national institutions now explicitly stress the endogenous nature of bank loans and monetary reserves. They also question the financial intermediation view of banks and the money-multiplier story (Jakab/Kumhof 2015; McLeay et al. 2014; Sheard 2013; also Lavoie 2010). Arguably, the most important attempt to amend the dominant NCM model in order to account for the EMT, thereby explicitly rejecting loanable funds theory, was made by Jakab/Kumhof (2015). These authors openly recognise that in the real world, the key function of banks is the provision of financing, or the creation of new monetary purchasing power through loans, for a single agent that is both borrower and depositor' (ibid.: 2, emphasis in original). As a result, they put forward a fundamental distinction between the old 'intermediation of loanable funds' (ILF) banking model (including both the pure intermediation and the money-multiplier models) and the 'financing through money creation' (FMC) banking model. The ILF banking model is (either explicitly or implicitly) used by neoclassical and Monetarist-like theories and models. By contrast, the FMC banking model shows a noteworthy resemblance to the banking model developed by Basil Moore (1988) and endogenous money theorists more generally. It explicitly recognises that banks can create money out of thin air, and that loans generate deposits, and deposits make monetary reserves. Jakab/Kumhof (2015: 39) also acknowledge that following 'identical shocks, FMC models predict changes in bank lending that are far larger, 
happen much faster, and have much larger effects on the real economy than otherwise identical ILF models, while the adjustment process depends much less on changes in lending spreads'. These findings are consistent with the available empirical evidence, which shows that lending is characterised by large jumps, bank leverage ratios behave pro-cyclically and credit is rationed during downturns.

Other prominent mainstream economists have also stressed arguments that undermine the exogenous money theory, including the distinction between financing and funding/ saving (Borio/Disyatat 2010; 2011), the residual nature of monetary aggregates and the dominance of loans over deposits (Disyatat 2011), the fallacy of the 'deposit multiplier' view (Carpenter/Demiralp 2012; Kydland/Prescott 1990; Lombra 1992) and the passive role of central banks in providing monetary reserves to the banking system (Dudley 2009). However, these arguments are seldom embedded in formal DSGE models or (conventional) structural macroeconometric models. This is likely due to the 'need' to anchor the long-run dynamics of the model to a natural level of output and interest rate (for some exceptions, though, see Goodfriend/McCallum 2007; Chari/Phelan 2014). Since proponents of the EMT reject the concept of the natural rate of interest (NRI), this raises the question, best illustrated by the competing interpretations of the monetary writings of Wicksell (1898 [1936]; 1906 [1935]), if the concept of the NRI is reconcilable with the view of an endogenous supply of money (Fontana 2011).

In short, for all progress made in rejecting some of its most extreme versions of the exogenous money view and its policy implications, mainstream theorists and policymakers consider the endogeneity of the money supply as either a mere historical accident or an empirical expedient, a residual in a set of formal equations. They have not embraced the EMT.

\section{ENDOGENOUS MONEY: NON-MAINSTREAM THEORY AND POLICY-MAKING}

While the mainstream literature has been forced by the GFC and other real-world events to introduce endogenous money arguments into its models, the non-mainstream (or, broadly defined, post-Keynesian economics) literature has continued to develop the EMT and its policy implications. The rest of this section will briefly summarise the main features of the EMT, before reviewing two significant recent advances, namely modern monetary theory (MMT; also labelled neo-Chartalism) and SFC contributions to monetary analysis.

\subsection{Horizontalists, structuralists and the single-period/continuation analyses of endogenous money}

Endogenous money theorists reject the idea of a unique NRI determined in the loanable funds market (Rogers 1989; Smithin 2002). There are a variety of financial assets, each with its own interest rate. The base or benchmark interest rate is a monetary variable, targeted by the central bank. The use of the concept of a production function for money is misleading, because money is not a commodity (Fontana 2003) but a social relationship. Money usually arises from purposeful interactions between two macroeconomic private groups, traditionally firms and workers, and commercial banks. In a similar fashion, money arises as a result of the triangular relationship involving the government (or Treasury), the private sector, and the central bank (or monetary authorities). Whatever the channel of creation, money is always created in the form of a credit (Graziani 2003). 
As such, it requires no abstinence or prior savings. According to the first channel described above, the amount of money circulating in the economy is determined by the private demand for bank loans, which are used to finance the production process or the upsurge of speculative purchases. A fundamental corollary follows: money is never neutral (Moore 1983). While the points above are now widely accepted by EMT scholars, there are (at least) two aspects of endogenous money theory that are still contentious. First, there is no full agreement over the 'degree' to which the central bank accommodates the demand for reserves of commercial banks. Second, there is no full agreement over the meaning and relevance of Keynes's concept of liquidity preference, and its application to the behaviour of the central bank, commercial banks and other financial intermediaries, respectively (Lavoie 1996; Moore 1998; Palley 1998). These two contentious aspects of the endogenous money theory are often presented in terms of the debate between the horizontalist or accommodationist approach and the structuralist approach to the EMT.

The horizontalist approach to the EMT is often associated with the works of Kaldor (1970; 1982), Lavoie (1992), Moore (1988; 1989) and Weintraub (1978). The horizontalist approach also shows a noteworthy resemblance to the MCT developed mainly by French and Italian authors since the mid 1970s (Barrère 1983; 1990; Graziani 1977; 1984; 1989; 1994; 2003; Parguez 1975; 1996; 2001; Poulon 1982). The overall endogenous process of money creation, as defined by the horizontalist approach, can be represented through a four-quadrant diagram (Fontana/Setterfield 2009a; 2009b; Palley 1996a). The north-west diagram of Figure 1 shows that the central bank steers the base interest rate, $r^{*}$, which is the reference rate for the banking sector. The supply of bank loans can then be portrayed as a horizontal line at the rate $r_{0}$, which includes a fixed mark-up, $m$, over $r_{0}$ determined by the monopoly power of banks, a liquidity

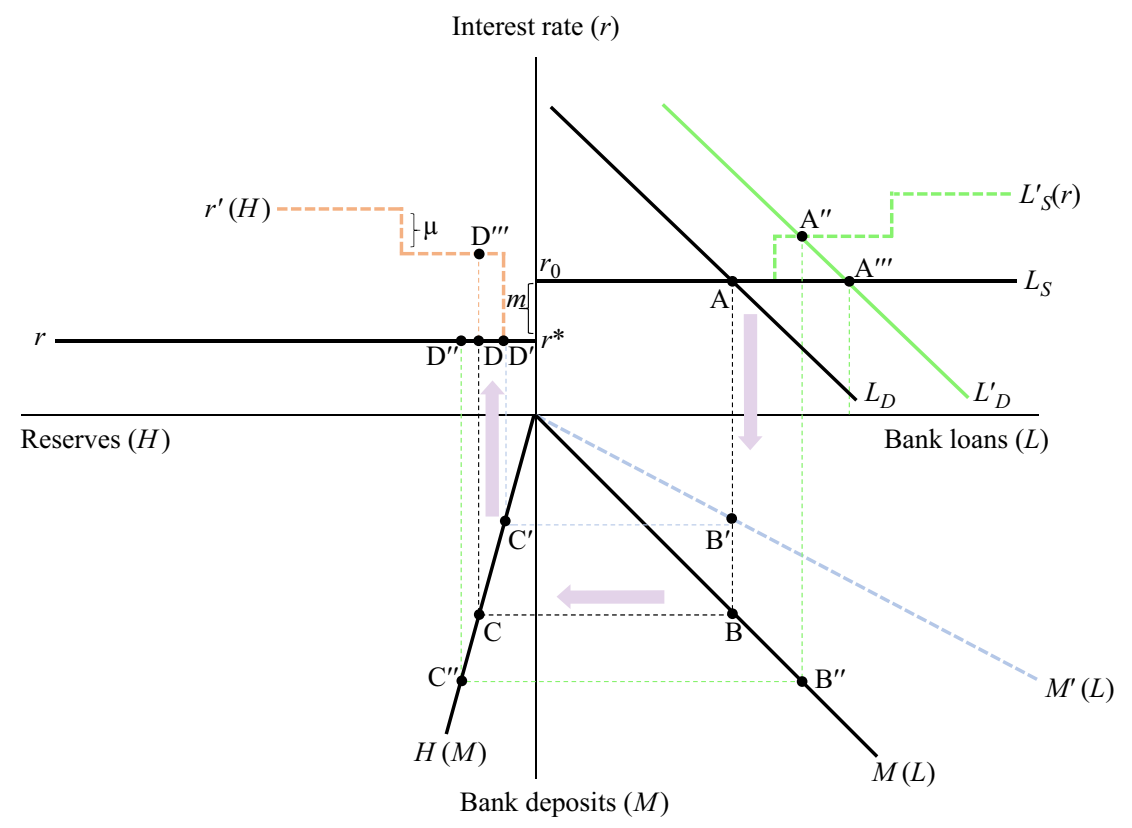

Source: Authors' illustration based on Fontana/Setterfield (2009b).

Figure 1 The endogenous money-supply process 
and risk premium and the value of the collateral of borrowers. The intersection between the demand for and the supply of loans determines the actual amount of loans and via the $M(L)$ line, the stock of bank deposits. Finally, if banks hold a certain percentage of (either compulsory or voluntary) reserves, the amount of reserves is determined via the $H(M)$ line in the south-west quadrant. The main features of the horizontalist approach are sketched in the fourth row of Table 1 .

The horizontalist representation of an infinitely elastic money-supply function has been questioned by the 'structuralist' approach to the EMT that focuses on the liquidity preference of the macro agents involved in the money-supply process. The structuralist approach is typically associated with the pioneering contributions of Chick (1983), Minsky (1982) and Rousseas (1986), and then developed by the works of (among others) Arestis (1997), Dow (1997), Howells (1995), Palley (1996b) and Pollin (1991). Structuralists emphasise the importance of liquidity preference both on the theoretical side (Cottrell 1986; Dow 1997; Wray 1990; 1995) and on the empirical side (Arestis/Mariscal 1995; Dow/Smithin 1999; Hewitson 1997; Howells/Hussein 1997; 1999; Palley 1994). They argue that liquidity preference does not refer to the demand for non-interest-bearing money only. On the contrary, liquidity preference must be extended to embrace all credit-debit relations and other balance-sheet interconnections across households, firms, commercial banks, financial intermediaries and the central bank (Bibow 1998; Dow 1996; Wray 1995). Economic agents narrow down their own portfolio of assets, while shifting towards highly liquid assets, as uncertainty and thus liquidity preference intensify. This affects the overall process of money creation. The structuralist approach can be represented by amending in Figure 1 the base interest-rate curve in the market for reserves and the loans-supply curve in the credit market. Both curves now assume a 'step' shape - see $r^{\prime}(H)$ and $L_{S}^{\prime}(r)$, respectively. All in all, the structuralist approach is not a different theory of money vis-à-vis the horizontalist approach. On the contrary, it has been convincingly argued that 'the common ground is potentially much larger than is commonly apparent' (Chick/Dow 2013: 152). While the horizontalist approach is aimed at highlighting the key features of the process of money creation, circulation and destruction under a single-period time framework, when the expectations of all macro agents involved in the money-supply process are given, the structuralist approach allows for a continuation time framework, where expectations are allowed to change and impact on the moneysupply process (Fontana 2003).

\subsection{Modern monetary theory (MMT) or neo-Chartalism}

Modern monetary theory (MMT) or neo-Chartalism is one of the most important recent developments of the EMT. While its description of the circuit of money payments resembles horizontalist analyses, the emphasis on state money and the innovative behaviour of banks brings it close to the structuralist view (Wray 2007: 12-17). Rows 3 to 6 in Table 1 show that the three main approaches to the EMT share the same view about the nature and roles of money in modern economies. MMT has been mainly developed by US authors since the early 1990s (Tcherneva 2006). Building upon the path-breaking contribution of Knapp (1924) and Lerner (1943), these authors have focused on the relationships between the government, the central bank, and the clearing and settlement systems. They argue that the general acceptance of money is due to the state requiring taxes to be paid in domestic currency. Neo-Chartalists stress that monetarily sovereign governments are the monopoly suppliers of their own currencies. As a result, (involuntary) insolvency and bankruptcy of monetarily sovereign governments 
is simply not possible. Since governments are not financially constrained in the way that non-sovereign units are, governments should focus on full employment (along with price stability). While some statements of the MMT may sound too simplistic and hence controversial, there is a common theoretical core with other approaches to the EMT, as they all agree that money has the nature of a credit-debit relationship and it is endogenously created and demand-led (Lavoie 2013; 2014).

From at least Horizontalists and Verticalists (Moore 1988), the EMT has been one of the main contributions of post-Keynesian and other non-mainstream economics. Yet, as argued in the previous section and with few noteworthy exceptions (Goodhart 1995; 2013a; 2013b), it has not been embraced by both mainstream economists and policymakers around the world. One of the major but rarely acknowledged merits of MMT has been to bring the EMT to the attention of a very large audience of policy-makers, politicians and the public at large. In this regard, it is worth highlighting an interesting strategy of supporters of the MMT. While for decades many EMT scholars have tried - sadly with mixed success - to dialogue with the most open-minded mainstream economists and policy-makers (Fontana 2002; Fontana/Setterfield 2009b), MMT scholars have preferred to dialogue directly with policy-makers and the public at large. Their success among the latter has then forced many mainstream economists to engage with the EMT and its policy implications. ${ }^{2}$

\subsection{Modelling endogenous money: stock-flow consistent models}

Since 2004, a new approach to modelling the EMT has been developed thanks to the ground-breaking contributions of Godley/Cripps (1983), Godley (1999), Taylor (2004) and especially Godley/Lavoie (2007). These contributions are usually associated with the inception of the so-called 'stock-flow consistent' (SFC) approach to macroeconomic dynamics (Caverzasi/Godin 2013; 2015; Nikiforos/Zezza 2017). The key features of the SFC approach are: (a) the explicit consideration of both flow and stock variables and the related macro-accounting consistency constraints; (b) the use of dynamic macroeconomic models, where endogenous variables move forward non-ergodically in historical time, to analyse their reaction to shocks to key parameters and exogenous variables; (c) the inclusion of a variety of sectors, real and financial assets and return rates; and (d) the development and use of several stock-flow ratios as indices of financial fragility. Notice that, unlike real assets, financial assets held by an agent or sector have an accounting counterpart in the liability side of the balance sheets of other agents or sectors. In SFC models, each financial stock is associated with its own flow, meaning that the former is continuously fuelled by (and, in turn, fuels) the latter. This is coherent with the 'quadruple accounting' principle, according to which any economic transaction requires at least four recorded entries for the accounting matrices to balance out (Copeland 1949; Godley/Lavoie 2007; Lavoie 2014).

The SFC approach gives a sense of formality to the EMT. It allows modelling of the key relationships stressed by horizontalist authors, while accounting also for the more complex institutional setting emphasised by the structuralists. The potential of the SFC approach is yet to be explored completely. For instance, a brand-new class of SFC models

2. Some EMT scholars question whether the MMT project helps or hinders the EMT, on the basis that some of its claims are too simplistic. They fear that mainstream economists will reject the EMT by virtue of rejecting these allegedly simplistic, policy-making-led claims of MMT scholars, thus throwing out the baby with the bath water. 
has recently been developed with the goal of analysing financial instability, asset bubbles and bankruptcy chain reactions (see, for the propagation of shocks through network-based balance-sheet relationships, Caiani et al. 2016). These models combine the SFC approach with agent-based $(\mathrm{AB})$ modelling techniques, providing the former with microfoundations for heterogeneous interacting agents. The novelty of AB-SFC models compared with standard (aggregate) SFC models is the 'granularity' of the analysis, allowing for a plurality of commercial banks interacting with a plurality of firms and households, in addition to a central bank. The stock-flow consistency of the system as a whole is no longer a macroeconomic constraint, as it now arises from accurate double-entry book-keeping at the level of the individual agent. It is sometimes assumed that each individual bank must meet a certain capital adequacy ratio requirement, but this is a controversial matter among $\mathrm{AB}$ modellers. The liquidity ratio, in contrast, is never assumed to constrain the decisions of individual commercial banks, as it is usually recognised that the central bank provides the banking system with the required amount of monetary reserves. From this viewpoint, AB-SFC models fully adhere to the EMT. Finally, it is worth highlighting that, in largescale AB-SFC models, initial stocks are usually calibrated in such a way that firms are allowed to hold already-accumulated deposits (or cash) at the beginning of the period, which can be used to finance the production and investment plans of firms. This departure from the standard EMT is a modelling choice, made for the sake of 'realism' and/or calibration purposes. As such, it does not affect the theoretical nature of AB-SFC models, which remain well grounded in the EMT.

In short, the main conclusion of this section is that, as mainstream theorists and policymakers have failed to embrace the original tenets of the EMT, the EMT itself has moved on, due among other things to: (a) a generalised theory of the endogenous process of money creation based on the distinction between single- and continuation-period analyses; (b) the increasing popularity of the MMT in the public debate; and (c) the development of aggregative stock-flow consistent (SFC) models and agent-based stock-flow consistent (AB-SFC) models.

\section{CONCLUSIONS}

The last decade or so has witnessed interesting developments in monetary economics and central banking. The EMT has been gradually clawing back popularity at the expense of the classical theory of the interest rate, the financial intermediation view of banks, the money-multiplier story and the quantity theory of money. Significantly, the decline of the exogenous view of money has also affected standard macroeconomic modelling, paving the way for the development of both a new generation of endogenous-money-like DSGE models.

However, while both the endogeneity of money and the use of interest rates as the key monetary policy tool have been long recognised by most central bankers and practitioners, mainstream scholars have found it hard to reject the main principles of the exogenous money view. In addition, although current mainstream macroeconomic models define money as an endogenous variable, the dynamic process of creation, circulation and destruction of money is usually neglected. The point is that the endogenous creation of bank loans and monetary reserves is still regarded by many mainstream economists and central bankers as a mere empirical or transitory historical circumstance, not a key feature of capitalist economies to be properly explained by a logically consistent theory.

Meanwhile, non-mainstream economists have further advanced the EMT, through (among other things): (a) a generalised theory of money based on the single- and 
continuation-period time-framework analyses; (b) the highly popular, policy-makingdriven MMT; and (c) aggregative stock-flow consistent (SFC) models and agent-based stock-flow consistent (AB-SFC) models. This leaves both mainstream theorists and policy-makers with an even bigger job to do, if they are ever to finally and properly come to grips with the main tenets of the EMT.

\section{ACKNOWLEDGEMENT}

The authors thank Mark Setterfield and the two anonymous referees for their comments and suggestions, which have helped to improve their paper considerably.

\section{REFERENCES}

Adam, K., Billi, R.M. (2007): Discretionary monetary policy and the zero lower bound on nominal interest rates, in: Journal of Monetary Economics, 54(3), 728-752.

Arestis, P. (1997): PKE theoretical aspects of money and finance, in: Arestis, P., Money, Pricing, Distribution and Economic Integration, New York: Springer, 55-73.

Arestis, P., Mariscal, I.B.-F. (1995): The endogenous money stock: empirical observations from the United Kingdom, in: Journal of Post Keynesian Economics, 17(4), 545-559.

Bank of England (1999): The transmission mechanism of monetary policy, in: Quarterly Bulletin, Monetary Policy Committee, Bank of England, 39, 1-12.

Barrère, A. (1983): Déséquilibres économiques et contre-révolution keynésienne: Keynes, seconde lecture, Paris: Economica.

Barrère, A. (1990): Signification générale du circuit: une interprétation, in: Economies et Sociétés, 24(2), 9-34.

Bernanke, B.S., Laubach, T., Mishkin, F.S., Posen, A.S. (1999): Inflation Targeting: Lessons from the International Experience, Princeton, NJ: Princeton University Press.

Bibow, J. (1998): On Keynesian theories of liquidity preference, in: The Manchester School, 66(2), 238-273.

Bindseil, U. (2004): Monetary Policy Implementation: Theory, Past, and Present, Oxford: Oxford University Press.

Blinder, A.S. (1997): Distinguished lecture on economics in government: what central bankers could learn from academics - and vice versa, in: Journal of Economic Perspectives, 11(2), 3-19.

Borio, C.E., Disyatat, P. (2010): Unconventional monetary policies: an appraisal, in: The Manchester School, 78(s1), 53-89.

Borio, C.E., Disyatat, P. (2011): Global imbalances and the financial crisis: link or no link? Bank of International Settlements Working Papers, No 346, URL: https://www.bis.org/publ/work346. pdf.

Caiani, A., Godin, A., Caverzasi, E., Gallegati, M., Kinsella, S., Stiglitz, J.E. (2016): Agent based stock flow consistent macroeconomics: towards a benchmark model, in: Journal of Economic Dynamics and Control, 69, 375-408.

Carpenter, S., Demiralp, S. (2012): Money, reserves, and the transmission of monetary policy: does the money multiplier exist?, in: Journal of Macroeconomics, 34(1), 59-75.

Caverzasi, E., Godin, A. (2013): Stock-flow consistent modeling through the ages, Levy Economics Institute of Bard College Working Paper 745.

Caverzasi, E., Godin, A. (2015): Post-Keynesian stock-flow-consistent modelling: a survey, in: Cambridge Journal of Economics, 39(1), 157-187.

Cecchetti, S.G., Schoenholtz, K.L., Fackler, J. (2006): Money, Banking, and Financial Markets, Vol. 4, New York: McGraw-Hill/Irwin.

Chari, V., Phelan, C. (2014): On the social usefulness of fractional reserve banking, in: Journal of Monetary Economics, 65, 1-13. 
Chick, V. (1983): Macroeconomics After Keynes: A Reconsideration of the General Theory, Cambridge, MA: MIT Press.

Chick, V., Dow, S. (2013): Post-Keynesian theories of money and credit, in: Harcourt, G.C., Kriesler, P. (eds), The Oxford Handbook of Post-Keynesian Economics: Critiques and Methodology, Vol. 2, Oxford: Oxford University Press, 152-167.

Clarida, R., Gali, J., Gertler, M. (1999): The science of monetary policy: a new Keynesian perspective, in: Journal of Economic Literature, 37(4), 1661-1707.

Copeland, M.A. (1949): Social accounting for moneyflows, in: The Accounting Review, 24(3), 254-264.

Cottrell, A. (1986): The endogeneity of money and money-income causality, in: Scottish Journal of Political Economy, 33(1), 2-27.

Davidson, P. (1978): Money and the real world, in: The Economic Journal, 82(325), 101-115.

De Grauwe, P., Ji, Y. (2013): Fiscal implications of the ECB's bond buying program, in: Open Economies Review, 24(5), 843-852.

Disyatat, P. (2011): The bank lending channel revisited, in: Journal of Money, Credit and Banking, 43(4), 711-734.

Dow, S.C. (1996): Keynes's philosophy and post Keynesian monetary theory, in: Arestis, P. (ed.), Keynes, Money and the Open Economy: Essays in Honour of Paul Davidson, Cheltenham, UK and Brookfield, VT: Edward Elgar Publishing, 34-49.

Dow, S.C. (1997): Endogenous money, in: Harcourt, G.C., Riach, P.A. (eds), A 'Second Edition' of The General Theory, London: Routledge, 61-78.

Dow, S.C. (2015): Liquidity trap, in: Rochon, L.-P., Rossi, S. (ed.), The Encyclopedia of Central Banking, Cheltenham, UK and Northampton, MA: Edward Elgar Publishing, 300-302.

Dow, S.C., Smithin, J. (1999): The structure of financial markets and the 'first principles' of monetary economics, in: Scottish Journal of Political Economy, 46(1), 72-90.

Dudley, W. (2009): The economic outlook and the Fed's balance sheet: the issue of 'how' versus 'when', Remarks at the Association for a Better New York, Breakfast Meeting, 29 July.

Eggertsson, G.B., Krugman, P. (2012): Debt, deleveraging, and the liquidity trap: a Fisher-MinskyKoo approach, in: Quarterly Journal of Economics, 127(3), 1469-1513.

Federal Reserve Board (1996): A guide to FRB/US: a macroeconomic model of the United States, Federal Reserve Board, Division of Research and Statistics, October.

Fontana, G. (2000): Post Keynesians and Circuitists on money and uncertainty: an attempt at generality, in: Journal of Post Keynesian Economics, 23(1), 27-48.

Fontana, G. (2002): The making of monetary policy in endogenous money theory: an introduction, in: Journal of Post Keynesian Economics, 24(4), 503-509.

Fontana, G. (2003): Post Keynesian approaches to endogenous money: a time framework explanation, in: Review of Political Economy, 15(3), 291-314.

Fontana, G. (2004): Rethinking endogenous money: a constructive interpretation of the debate between horizontalists and structuralists, in: Metroeconomica, 55(4), 367-385.

Fontana, G. (2011): The role of money and interest rates in the theory of monetary policy: an attempt at perspective, in: History of Economic Ideas, 19(3), 113-134.

Fontana, G., Palacio-Vera, A. (2004): Monetary policy uncovered: theory and practice, in: International Review of Applied Economics, 18(1), 25-41.

Fontana, G., Setterfield, M. (2009a): Macroeconomics, endogenous money and the contemporary financial crisis: a teaching model, in: International Journal of Pluralism and Economics Education, $1(1-2), 130-147$.

Fontana, G., Setterfield, M. (2009b): A simple (and teachable) macroeconomic model with endogenous money, in: Fontana, G., Setterfield, M., Macroeconomic Theory and Macroeconomic Pedagogy, New York: Springer, 144-168.

Friedman, B.M. (1990): Targets and instruments of monetary policy, in: Handbook of Monetary Economics, 2, 1185-1230.

Fullwiler, S.T. (2003): Timeliness and the Fed's daily tactics, in: Journal of Economic Issues, 37(4), 851-880.

Fullwiler, S.T. (2013): An endogenous money perspective on the post-crisis monetary policy debate, in: Review of Keynesian Economics, 1(2), 171-194. 
Gambacorta, L., Hofmann, B., Peersman, G. (2014): The effectiveness of unconventional monetary policy at the zero lower bound: a cross-country analysis, in: Journal of Money, Credit and Banking, 46(4), 615-642.

Godley, W. (1999): Money and credit in a Keynesian model of income determination, in: Cambridge Journal of Economics, 23(4), 393-411.

Godley, W., Cripps, F. (1983): Macroeconomics, London: Fontana.

Godley, W., Lavoie, M. (2007): Monetary Economics: An Integrated Approach to Credit, Money, Income, Production and Wealth, Basingstoke, UK: Palgrave Macmillan.

Goodfriend, M., McCallum, B.T. (2007): Banking and interest rates in monetary policy analysis: a quantitative exploration, in: Journal of Monetary Economics, 54(5), 1480-1507.

Goodhart, C. (1995): Money supply control: base or interest rates?, in: Goodhart, C., The Central Bank and the Financial System, London: Springer, 249-262.

Goodhart, C. (2013a): The endogeneity of money, in: Arestis, P., Desai, M., Dow, S. (eds), Money, Macroeconomics and Keynes, Abingdon, UK: Routledge, 26-36.

Goodhart, C. (2013b): The potential instruments of monetary policy, in: Central Bank Review, $13(2), 1-15$.

Graziani, A. (1977): Scambi simultanei e successione ciclica nel processo economico, in: Quaderni piacentini, 64(1), 113-137.

Graziani, A. (1984): Moneta senza crisi, in: Studi Economici, 39(24), 3-37.

Graziani, A. (1989): The theory of the monetary circuit, Thames Papers in Political Economy, Spring. (Reprinted in Musella, M., Panico, C. (eds) (1995), The Money Supply in the Economic Process, Aldershot, UK and Brookfield, VT: Edward Elgar Publishing.)

Graziani, A. (1994): La teoria monetaria della produzione, Arezzo: Banca popolare dell'Etruria e del Lazio.

Graziani, A. (2003): The Monetary Theory of Production, Cambridge, UK: Cambridge University Press.

Hamilton, J.D., Wu, J.C. (2012): The effectiveness of alternative monetary policy tools in a zero lower bound environment, in: Journal of Money, Credit and Banking, 44(s1), 3-46.

Hewitson, G. (1997): The Post-Keynesian demand for credit model, in: Australian Economic Papers, 36(68), 127-143.

Hicks, J. (1967): Critical Essays in Monetary Theory, Oxford: Clarendon Press.

Howells, P. (1995): Endogenous money, in: International Papers in Political Economy, 2(2), 1-41.

Howells, P., Hussein, K. (1997): The demand for money: total transactions as the scale variable, in: Economics Letters, 55(3), 371-377.

Howells, P., Hussein, K. (1999): The demand for bank loans and the 'state of trade', in: Journal of Post Keynesian Economics, 21(3), 441-454.

Jakab, Z., Kumhof, M. (2015): Banks are not intermediaries of loanable funds - and why this matters, Bank of England Working Paper, 529.

Kahn, R.F. (1972): Selected Essays on Employment and Growth, Cambridge, UK: Cambridge University Press.

Kaldor, N. (1970): The new monetarism, in: Lloyds Bank Review, 97(1), 1-17.

Kaldor, N. (1982): The Scourge of Monetarism, Oxford: Oxford University Press.

Keynes, J.M. (1936 [2012]): The General Theory of Money, Interest and Employment, reprinted in: Johnson, E., Moggridge, D. (eds), The Collected Writings of John Maynard Keynes, Volume 7, Cambridge, UK: Cambridge University Press and the Royal Economic Society, URL: https:// www.cambridge.org/core/series/collected-writings-of-john-maynard-keynes/76BAC759DE69633B 2FE5A471646FE40E.

Knapp, G.F. (1924): The state theory of money, McMaster University Archive for the History of Economic Thought.

Kregel, J. (2000): Krugman on the liquidity trap: why inflation won't bring recovery in Japan, Levy Economics Institute Working Paper, 298.

Krugman, P.R., Dominquez, K.M., Rogoff, K. (1998): It's baaack: Japan's slump and the return of the liquidity trap, in: Brookings Papers on Economic Activity, 1998(2), 137-205.

Kydland, F.E., Prescott, E.C. (1990): Business cycles: real facts and a monetary myth, in: Quarterly Review, 12(4), 3-18. 
Laidler, D. (2002): The transmission mechanism with endogenous money, in: Arestis, P., Desai, M., Dow, S. (eds), Money Macroeconomics and Keynes: Essays in Honour of Victoria Chick, Vol. 1, London: Routledge, 25-34.

Lavoie, M. (1992): Foundations of Post-Keynesian Economic Analysis, Aldershot, UK and Brookfield, VT: Edward Elgar Publishing.

Lavoie, M. (1996): Horizontalism, structuralism, liquidity preference and the principle of increasing risk, in: Scottish Journal of Political Economy, 43(3), 275-300.

Lavoie, M. (2010): Changes in central bank procedures during the subprime crisis and their repercussions on monetary theory, in: International Journal of Political Economy, 39(3), 3-23.

Lavoie, M. (2013): The monetary and fiscal nexus of neo-chartalism: a friendly critique, in: Journal of Economic Issues, 47(1), 1-32.

Lavoie, M. (2014): Post-Keynesian Economics: New Foundations, Cheltenham, UK and Northampton, MA: Edward Elgar Publishing.

Lavoie, M. (2017): Rethinking monetary theory in light of Keynes and the crisis, in: Brazilian Keynesian Review, 2(2), 174-188.

Le Bourva, J. (1962): Création de la monnaie et multiplicateur du crédit, in: Revue économique, 13(1), $29-56$.

Le Bourva, J. (1992): Money creation and credit multipliers, in: Review of Political Economy, 4(4), $447-466$.

Lerner, A.P. (1943): Functional finance and the federal debt, in: Social Research, 10(1), 38-51.

Lombra, R.E. (1992): Understanding the remarkable survival of multiplier models of money stock determination, in: Eastern Economic Journal, 18(3), 305-314.

Mankiw, G. (2009): The disappearing money multiplier, Greg Mankiw’s Blog, 5 January.

McCallum, B.T. (2000): Theoretical analysis regarding a zero lower bound on nominal interest rates, National Bureau of Economic Research, Working Paper No 7677.

McLeay, M., Radia, A., Thomas, R. (2014): Money creation in the modern economy, in: Bank of England Quarterly Bulletin, Q1, 14-27.

Minsky, H.P. (1982 [2015]): Can 'It' Happen Again? Essays on Instability and Finance, Abingdon, UK: Routledge.

Moore, B.J. (1983): Unpacking the post Keynesian black box: bank lending and the money supply, in: Journal of Post Keynesian Economics, 5(4), 537-556.

Moore, B.J. (1988): Horizontalists and Verticalists: The Macroeconomics of Credit Money, Cambridge, UK: Cambridge University Press.

Moore, B.J. (1989): On the endogeneity of money once more, in: Journal of Post Keynesian Economics, 11(3), 479-487.

Moore, B.J. (1998): Accommodation to accommodationism: a note, in: Journal of Post Keynesian Economics, 21(1), 175-178.

Nikiforos, M., Zezza, G. (2017): Stock-flow consistent macroeconomic models: a survey, in: Journal of Economic Surveys, 31(5), 1204-1239.

Palley, T.I. (1994): Competing views of the money supply process: theory and evidence, in: Metroeconomica, 45(1), 67-88.

Palley, T.I. (1996a): Accommodationism versus structuralism: time for an accommodation, in: Journal of Post Keynesian Economics, 18(4), 585-594.

Palley, T.I. (1996b): Post Keynesian Economics: Debt, Distribution and the Macro Economy, London: Macmillan.

Palley, T.I. (1998): Accommodationism, structuralism, and superstructuralism, in: Journal of Post Keynesian Economics, 21(1), 171-173.

Palley, T.I. (2002): Endogenous money: what it is and why it matters, in: Metroeconomica, 53(2), $152-180$.

Parguez, A. (1975): Monnaie et macroéconomie: théorie de la monnaie en déséquilibre, Paris: Economica.

Parguez, A. (1984): La dynamique de la monnaie in la monnaie dans un système dynamique: le modèle de formation du capital par le crédit, in: Economies et Sociétés, 18(4), 83-118.

Parguez, A. (1996): Beyond scarcity: a reappraisal of the theory of the monetary circuit, in: Deleplace, G., Nell, E. (eds), Money in Motion: The Post Keynesian and Circulation Approaches, London: Macmillan, 155-199. 
Parguez, A. (2001): Money without scarcity: from the horizontalist revolution to the theory of the monetary circuit, in: Rochon, L.-P., Vernegno, M. (eds), Credit, Interest Rates and the Open Economy: Essays in Horizontalism, Cheltenham, UK and Northampton, MA: Edward Elgar Publishing, 69-103.

Pollin, R. (1991): Two theories of money supply endogeneity: some empirical evidence, in: Journal of Post Keynesian Economics, 13(3), 366-396.

Poole, W. (1970): Optimal choice of monetary policy instruments in a simple stochastic macro model, in: Quarterly Journal of Economics, 84(2), 197-216.

Poulon, F. (1982): Macroéconomie approfondie: équilibre, déséquilibre, circuit, Paris : Editions Cujas.

Realfonzo, R. (1998): Money and Banking: Theory and Debate (1900-1940), Cheltenham, UK and Lyme, NH: Edward Elgar Publishing.

Robinson, J. (1956): The Accumulation of Capital, London: Macmillan.

Rogers, C. (1989): Money, Interest and Capital: A Study in the Foundations of Monetary Theory, Cambridge, UK: Cambridge University Press.

Romer, D.H. (2000): Keynesian macroeconomics without the LM curve, in: Journal of Economic Perspectives, 14(2), 149-169.

Rousseas, S. (1986): Post Keynesian Monetary Theory, London, UK and Armonk, NY: M.E. Sharpe.

Schmitt, B. (1960): Monnaie, salaires et profits, Paris: Presses Universitaires de France.

Schmitt, B. (1972): Macroeconomic Theory: A Fundamental Revision, Albeuve: Castella.

Schmitt, B. (1975): Théorie unitaire de la monnaie, nationale et internationale, Albeuve: Castella.

Schmitt, B. (1984): Inflation, chômage et malformations du capital: macroéconomie quantique, Albeuve: Castella and Paris: Économica.

Schumpeter, J.A. (1954): History of Economic Analysis, Schumpeter, E.B. (ed.), New York: Oxford University Press.

Sheard, P. (2013): Repeat after me: banks cannot and do not 'lend out' reserves, Credit Market Services, Standard and Poor's, URL: http://issuu. com/positivemoney/docs/sp-banks-cannot-anddonotlend-out.

Smithin, J. (2002): Interest parity, purchasing power parity, 'risk premia', and Post Keynesian economic analysis, in: Journal of Post Keynesian Economics, 25(2), 219-235.

Summers, L.H. (2014): US economic prospects: secular stagnation, hysteresis, and the zero lower bound, in: Business Economics, 49(2), 65-73.

Svensson, L.E.O. (1999): Price level targeting versus inflation targeting: a free lunch?, in: Journal of Money, Credit and Banking, 31(3), 277-295.

Taylor, J.B. (1999): A historical analysis of monetary policy rules, in: Taylor, J.B. (ed.), Monetary Policy Rules, Chicago: University of Chicago Press, 319-348.

Taylor, J.B. (2000): Teaching modern macroeconomics at the principles level, in: American Economic Review, 90(2), 90-94.

Taylor, L. (2004): Exchange rate indeterminacy in portfolio balance, Mundell-Fleming and uncovered interest rate parity models, in: Cambridge Journal of Economics, 28(2), 205-227.

Tcherneva, P.R. (2006): Chartalism and the tax-driven approach to money, in: Arestis, P., Sawyer, M. (eds), A Handbook of Alternative Monetary Economics, Cheltenham, UK and Northampton, MA: Edward Elgar Publishing, 69-85.

Weintraub, S. (1978): Keynes, Keynesians, and Monetarists, Philadelphia: University of Pennsylvania Press.

Wicksell, K. (1898 [1936]): Interest and Prices: A Study of the Causes Regulating the Value of Money, Kahn, R.F. (trans.), London: Macmillan (orig. German edn: Geldzins und Güterpreise, bestimmenden Ursachen, J., Fischer, G., 1898).

Wicksell, K. (1906 [1935]): Lectures on Political Economy, vol. ii: Money, Classen, E. (trans.), Robbins, L. (ed.), London: Routledge Kegan Paul.

Woodford, M. (1996): Loan commitments and optimal monetary policy, in: Journal of Monetary Economics, 37(3), 573-605.

Wray, L.R. (1990): Money and Credit in Capitalist Economies: The Endogenous Money Approach, Aldershot, UK and Brookfield, VT: Edward Elgar Publishing.

Wray, L.R. (1995): Keynesian monetary theory: liquidity preference or black box horizontalism?, in: Journal of Economic Issues, 29(1), 273-282. 
Wray, L.R. (1998): Understanding Modern Money: The Key to Full Employment and Price Stability, Cheltenham, UK and Lyme, NH: Edward Elgar Publishing.

Wray, L.R. (2007): Endogenous money: structuralist and horizontalist, Levy Economics Institute Working Paper, 512.

Wright, J.H. (2012): What does monetary policy do to long-term interest rates at the zero lower bound?, in: Economic Journal, 122(564), F447-F466.

Wu, J.C., Xia, F.D. (2016): Measuring the macroeconomic impact of monetary policy at the zero lower bound, in: Journal of Money, Credit and Banking, 48(2-3), 253-291.

\section{FURTHER READING}

Burgess, S., Burrows, O., Godin, A., Kinsella, S., Millard, S. (2016): A dynamic model of financial balances for the United Kingdom, Bank of England Working Papers, Working Paper No 614.

Taylor, J.B. (1995): The monetary transmission mechanism: an empirical framework, in: Journal of Economic Perspectives, 9(4), 11-26. 